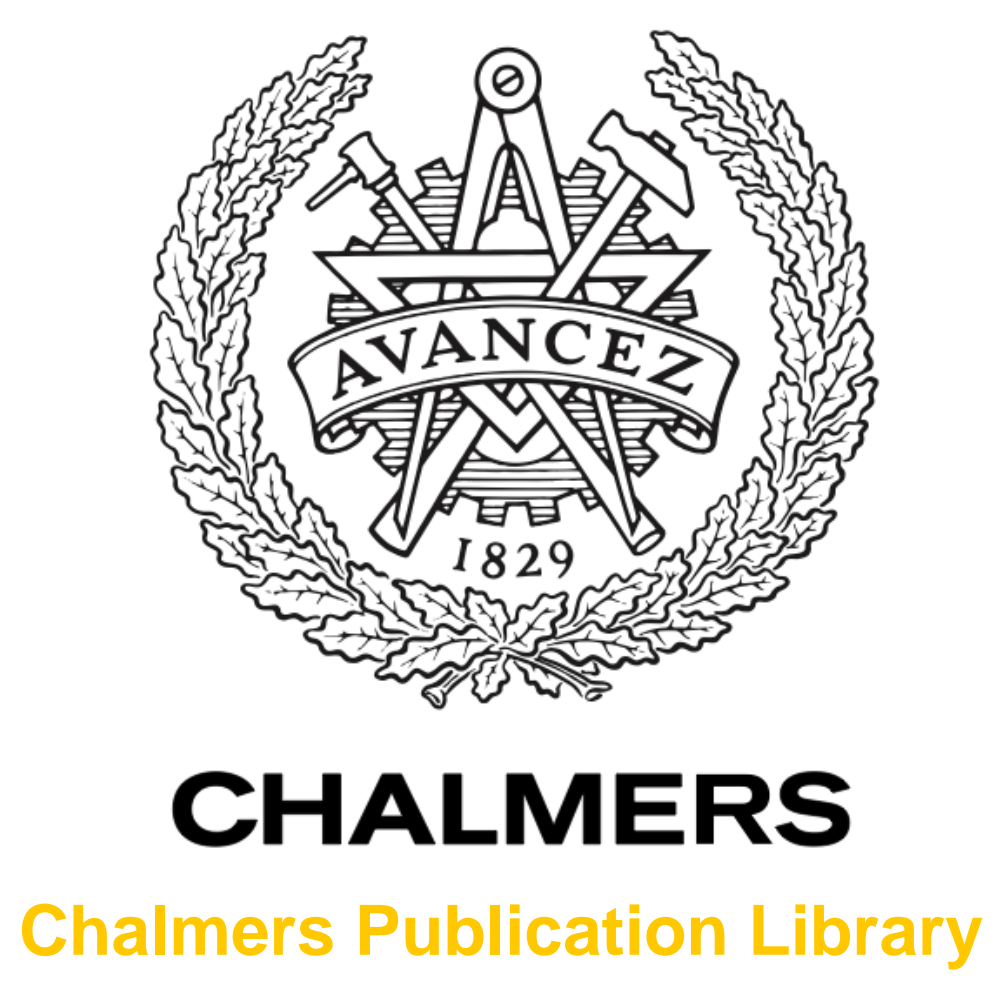

Perceptions of Local Sustainability in Planning Sanitation Projects in West Africa

This document has been downloaded from Chalmers Publication Library (CPL). It is the author's version of a work that was accepted for publication in:

The Sanititation Challenge Conference. May 19-21, 2008, Wageningen

Citation for the published paper:

McConville, J. ; Kain, J. ; Klutsé, A. et al. (2008) "Perceptions of Local Sustainability in Planning Sanitation Projects in West Africa". The Sanititation Challenge Conference. May 19-21, 2008, Wageningen

Downloaded from: http://publications.lib.chalmers.se/publication/75717

Notice: Changes introduced as a result of publishing processes such as copy-editing and formatting may not be reflected in this document. For a definitive version of this work, please refer to the published source. Please note that access to the published version might require a subscription.

Chalmers Publication Library (CPL) offers the possibility of retrieving research publications produced at Chalmers University of Technology. It covers all types of publications: articles, dissertations, licentiate theses, masters theses, conference papers, reports etc. Since 2006 it is the official tool for Chalmers official publication statistics. To ensure that Chalmers research results are disseminated as widely as possible, an Open Access Policy has been adopted.

The CPL service is administrated and maintained by Chalmers Library. 


\title{
Perceptions of Local Sustainability in Planning Sanitation Projects in West Africa
}

\author{
J. R. McConville ${ }^{1 *}$, J.H. Kain ${ }^{2}$, A. Klutsé ${ }^{3}$, and E. Kvarnström ${ }^{4}$ \\ ${ }^{1}$ Land \& Water Resources Engineering, Royal Institute of Technology, Teknikringen 76, SE- \\ 10044 Stockholm, Sweden (Email. jrmc@kth.se)*Corresponding author \\ ${ }^{2}$ Dept. of Architecture, Chalmers University of Technology, SE-412 96 Göteborg, Sweden \\ (Email: kain@chalmers.se) \\ ${ }^{3}$ CREPA Siège, 03 BP: 7112 Ouagadougou 03 Burkina Faso \\ (Email : amahklutse@yahoo.fr) \\ ${ }^{4}$ Stockholm Environment Institute, Kräftriket 2B, SE-10691 Stockholm, Sweden \\ (Email: elisabeth.kvarnstrom@sei.se)
}

\begin{abstract}
The purpose of this study was to examine local perceptions of sustainability in the context of sanitation interventions in Burkina Faso and Mali, West Africa. A series of interviews with local actors were used to define criteria for sustainable sanitation in the local context. These local criteria were compared with criteria found in international literature and planning practices used in two sanitation projects. The results from the interview study emphasize criteria related to behaviour change processes, while criteria in literature are either technically and best-practice oriented. The case studies show an attempt to merge academic and pragmatic perspectives by addressing both the technical requirements and social change processes, however challenges still remain for balancing the various criteria and achieving lasting sanitation improvements.
\end{abstract}

Keywords Criteria, Participative Planning, Perspectives, Sanitation, Sustainable

\section{INTRODUCTION}

The challenge of achieving global sanitation targets is that it requires both the application of technology that is appropriate and a supporting organizational structure. The term sanitation refers to the process of disposing of human excreta in a manner that protects public and environmental health. The United Nations Joint Monitoring Program defines improved sanitation as systems in which excreta are disposed of in a way that reduces the risk of faecal-oral disease transmission to users and the environment. However, as a fundamental part of daily life, sanitation systems are closely linked to societal issues of culture, technology, and economics. Therefore, to insure functioning systems it is necessary to use a more inclusive definition of sustainable sanitation: a system which protects and promotes human health, does not contribute to environmental degradation or depletion of the resource base, is technically and institutionally appropriate, economically viable and socially acceptable (Bracken et al., 2005). Although it is recognized that sustainability is highly site specific, there is a wide body of literature that attempts to categorize and generalize criteria necessary for a sanitation system to be sustainable, (e.g. Hellström et al., 2000; Balkema, 2002; Bracken et al., 2005). Criteria for health, environmental, economic, technical and socio-cultural aspects have been incorporated into sustainability assessments and decision-support models using tools such as life cycle assessment and cost-benefit analysis (Lundin, 2002; Van der Vleuten, 2003; McConville and Mihelcic, 2007). Increasingly, criteria are also being tied to process-oriented approaches in planning and implementation, such as the International Water 
Association's Sanitation 21 (IWA, 2006) and Household Centred Environmental Sanitation (Eawag, 2005). However, there are few cases where these frameworks have been fully implemented in the field and it is unclear how well such theoretical methods correspond to actual practices and experiences in the field.

The objectives of this study are therefore three-fold: (i) to examine local perceptions of criteria for sustainability in the context of sanitation interventions in Burkina Faso and Mali, West Africa, (ii) to compare those locally identified sustainability criteria with international sustainability criteria, and to (iii) compare the locally and internationally identified sustainability criteria with what is implemented on a project level in two case studies.

\section{METHODOLOGY}

The three objectives of this study were addressed through a combination of research methods. The first objective was achieved through a series of 20 interviews with key informants in Burkina Faso and Mali to define criteria of sustainable sanitation in the local context. The interviews were semi-structured, based on a list of guiding questions related to project planning, technology choice, and sustainability. Ten of the interviews were with personnel from the Regional Centre for Low-Cost Water and Sanitation (CREPA) and 10 with individuals from other institutions involved in sanitation. CREPA serves as an educational and research resource for the water and sanitation sector in French-speaking West Africa and has extensive experience working with communities to implement on-site, low-cost sanitation projects. By conducting additional interviews within this organization, the study was able to obtain perspectives from people with diverse roles and training: project managers, research specialists, technicians, and sociologists. The remaining 10 interviews covered the perspective from the other institutions involved in the sanitation sector: governmental agencies (ONEA, DGRE, Municipal Mayor), international NGOs (WaterAid, Plan, Helvetas), local NGO (Alphalog), and international donor organization (World Bank-WSP, UNICEF). The interviews were analyzed with the aid of the qualitative research software HyperRESEARCH 2.8. Through HyperRESEARCH the interview responses were coded and from these codes a number of sub-categories were discerned and eventually separated into four main categories of criteria for sustainable systems.

The second objective involved a review of international literature relating to criteria for sustainable sanitation and best practice recommendation from project implementation reports. The results were synthesized into a list of literature-based criteria which was compared to the responses from the interview study.

The third objective used two case studies of local sanitation planning processes to illustrate how the local actors are putting different criteria to use. The first case was the strategic sanitation plan for Ouagadougou, Burkina Faso (PSAO) and the second was the planning process used by the international NGO, WaterAid, to assist municipalities in reaching water and sanitation targets. Information for the case studies was gathered from planning documents, project reports, and interviews with key informants. 


\section{RESULTS: INTERVIEW STUDY}

The systematic, mainly qualitative, analysis of the interviews resulted in a list of locally grounded criteria for achieving sustainable sanitation, and also a local definition of sustainable development within the context of sanitation. Here, 'local' is defined as equivalent to the geographic and/or operational level where the interviewees are active. An important general observation is that, although the international community tends to use the inclusive definition of sustainability given above, among the local actors a simpler definition is often used. It was explicitly or implicitly stated by the 14 interviewees who defined sustainability during the interview that sustainable sanitation systems are ones that will endure and continue to provide benefits after the initial stimulus, support, and funding have ended. The representative from the international development agency, Plan, described a sustainable project as one where the "community exhibits ownership, people put hygiene/sanitation lessons into practice, and there is general cleanliness in the village”. As such, achieving results and lasting impacts means that behaviour change is evident among the population.

The criteria identified by the interviewees can be grouped into four main categories: (i) socio-cultural, (ii) economics, (iii) technical, and (iv) process (Table 1). Criteria for health (stated by 1 of 20 interviewees) and environmental (3/20) factors were rarely mentioned related to sustainability in the interviews.

\section{Socio-cultural}

All interviewees mentioned criteria related to socio-cultural and institutional factors. Many (12/20) of the interviewees mentioned the need for human resource development at both an institutional and household level. They stated that successful systems require proper usage, operation and maintenance $(\mathrm{O} \& \mathrm{M})$, and management structures for monitoring and evaluation (M\&E). If the local capacity is insufficient to provide these services, implementation of a sanitation system needs to be accompanied by capacity development programs.

Another emphasis (10/20) was on communication methods and collaboration between institutions. Communication channels were frequently cited as methods for reinforcing capacity and strengthening motivating for behaviour change through feedback sessions and learning networks. Closely related to communication were comments regarding the need for laws, policies and institutional frameworks for sanitation that are compatible with the current decentralization process.

Socio-cultural criteria also include factors related to acceptability (14/20), raising demand for sanitation and stimulating behaviour change (17/20). Interviewees stated that proposed sanitation systems must be culturally appropriate, compatible with local priorities, perceptions regarding excreta, and social value systems. However, it was also recognized that improving sanitation practices requires behaviour change and changing certain cultural aspects. Therefore, awareness-raising programs are used to motivate behaviour change and create demand for sanitation systems through education, capacity development, and empowering community action for change. 


\section{Economics}

Economic criteria identified during the interviews focused on issues of affordability $(11 / 20)$, marketing $(4 / 20)$, and financial management $(12 / 20)$. Due to generally high levels of poverty in the region, most actors agreed that the cost of the system needed to be estimated by life cycle costs, including O\&M, and be matched with what people are willing and able to pay. As members of Helvetas remarked, "75\% of decisions are based on cost". The question of affordability was often cited in relation to user choice, in the context that users would choose a technology that they could afford to operate and maintain. As one CREPA staff member stated, “...if it is not their choice, it is not sustainable”. However, it was also recognized that user choice could be influenced by awareness-raising efforts and/or social marketing. Interviewees citing market forces in sustainability pointed at the need to address the supply chain by developing local capacity to provide services and creating markets for technologies through service packages and advertising the benefits of sanitation. Underpinning issues of affordability and marketing, was the most frequently mentioned economic criteria: financial management. It was generally agreed that financing mechanisms are needed and that they must cover both installation and O\&M costs.

\section{Technical}

Technical criteria were not mentioned as often as the former categories, and when they were it was often in relation to socio-cultural issues, such as adaptation to the local community (cultural, environmental), repeatable, local capacity and willing to perform O\&M, and convenience. It was recognized that the choice of technical system will affect sustainability, but the process of making the choice and the participatory dialogue surrounding the choice was cited more often than specific technical indicators of success.

\section{Process}

These criteria relate to the process of implementing sanitation and include the use of participatory approaches, planning, and M\&E mechanisms. A majority of interviewees (16/20) cited participatory methods as necessary for sustainability. Interviewees described the need for participation and planning processes that are flexible, iterative, and inclusive of a variety of stakeholders, technical systems, and life cycle stages (implementation to O\&M). Process criteria are not independent of the other criteria; in fact they encompass the act of achieving them. Due to the frequency with which these issues were cited in the interviews they were considered important enough to be mentioned as a particular set of criteria. 
Table 1: Sustainability criteria identified by interviewees; including number of interviewees citing each category and the organizations they represent.

\begin{tabular}{|c|c|c|c|}
\hline Category & Description & $\begin{array}{l}\text { Cited } \\
(\mathbf{x} / \mathbf{2 0})\end{array}$ & Organizations \\
\hline Socio-cultural & & 20 & \\
\hline Capacity Building & $\begin{array}{l}\text { Organizational/Management skills, O\&M performance (proper usage), Training } \\
\text { for M\&E , Technology appropriation }\end{array}$ & 14 & $\begin{array}{l}\text { CREPA (6), Alphalog (2), DGRE, Mayor, } \\
\text { Helvetas, WaterAid, UNICEF, WSP }\end{array}$ \\
\hline $\begin{array}{l}\text { Institutional } \\
\text { Communication }\end{array}$ & $\begin{array}{l}\text { Communication plan between institutions, Involvement of key leaders, } \\
\text { Responsibility distribution }\end{array}$ & 13 & $\begin{array}{l}\text { CREPA (7), DGRE, Mayor, Helvetas,, } \\
\text { WaterAid, UNICEF, WSP }\end{array}$ \\
\hline Laws and Policy & $\begin{array}{l}\text { Functional Legal Framework, Institutional policy and politics, Compatible with } \\
\text { decentralization }\end{array}$ & 6 & CREPA (3), DGRE, Mayor, UNICEF \\
\hline $\begin{array}{l}\text { Cultural } \\
\text { Acceptability }\end{array}$ & $\begin{array}{l}\text { Compatible with local priorities and needs, Stigmas/perceptions of waste, } \\
\text { Cultural value systems (dignity, gender roles), Adapted to local context } \\
\text { (social calendar, prioritization of time, differing social strata) }\end{array}$ & 14 & $\begin{array}{l}\text { CREPA (7), Alphalog (1), DGRE, Mayor, } \\
\text { Helvetas, Plan, UNICEF, WSP }\end{array}$ \\
\hline $\begin{array}{l}\text { Awareness-Raising } \\
\text { for Behaviour } \\
\text { Change }\end{array}$ & $\begin{array}{l}\text { Knowledge exchange/education for informed choice, Communication, Creating } \\
\text { demand and awareness, Motivating change (authorities, early adopters), } \\
\text { Allowing time for behaviour change }\end{array}$ & 17 & $\begin{array}{l}\text { CREPA (9), DGRE, Mayor, ONEA, Helvetas, } \\
\text { Plan, WaterAid, UNICEF, WSP }\end{array}$ \\
\hline Economics & & 16 & \\
\hline Affordable & Based on total life cycle costs, Willingness to pay, Capacity to pay & 11 & $\begin{array}{l}\text { CREPA (5), Alphalog (1), DGRE, ONEA, } \\
\text { Helvetas, WaterAid, WSP }\end{array}$ \\
\hline Marketing & $\begin{array}{l}\text { Creating demand, Showing the benefits/value of sanitation, Offering service } \\
\text { packages, Creating markets, businesses, and jobs }\end{array}$ & 10 & $\begin{array}{l}\text { CREPA (5), Alphalog (1), ONEA, Helvetas, } \\
\text { UNICEF, WSP }\end{array}$ \\
\hline $\begin{array}{l}\text { Financial } \\
\text { Management }\end{array}$ & $\begin{array}{l}\text { Financing mechanisms (credit, subsidy, taxes), Cost recovery, Stability of } \\
\text { financing, Capital and O\&M costs, Locally available resources }\end{array}$ & 12 & $\begin{array}{l}\text { CREPA (5), Alphalog (2), DGRE, Mayor, } \\
\text { ONEA, WaterAid, WSP }\end{array}$ \\
\hline Technical & & 10 & \\
\hline $\begin{array}{l}\text { Adaptation to local } \\
\text { community }\end{array}$ & $\begin{array}{l}\text { Environmental constraints, Local capacity to replicate technology, Local } \\
\text { resources (human/material) available for O\&M }\end{array}$ & 6 & CREPA (3), DGRE, WaterAid, WSP \\
\hline O\&M requirements & $\begin{array}{l}\text { Local capacity/willingness to perform O\&M, Convenience/ease of maintenance, } \\
\text { O\&M requirements appropriate in cultural context }\end{array}$ & 7 & $\begin{array}{l}\text { CREPA (1), DGRE, Mayor, ONEA, Helvetas, } \\
\text { UNICEF, WSP }\end{array}$ \\
\hline Process & & 16 & \\
\hline Participation & $\begin{array}{l}\text { Participatory approach , Local organizations/leaders involved, User Choice, } \\
\text { Ownership }\end{array}$ & 16 & $\begin{array}{l}\text { CREPA (7), Alphalog (2), DGRE, Mayor,, } \\
\text { ONEA, Plan, WaterAid, UNICEF, WSP }\end{array}$ \\
\hline Planning & $\begin{array}{l}\text { Feasibility/appropriate technology, Life cycle perspective (especially } \\
\text { considering O\&M) }\end{array}$ & 8 & $\begin{array}{l}\text { CREPA (3), DGRE, Mayor, WaterAid, } \\
\text { UNICEF, WSP }\end{array}$ \\
\hline M\&E & Feedback and follow-up, Flexible iterative approach & 6 & CREPA (3), ONEA, WaterAid, UNICEF \\
\hline
\end{tabular}




\section{RESULTS: CRITERIA IN LITERATURE}

As previously stated, there is a wide body of literature that attempts to categorize and generalize criteria necessary for a sanitation system to be sustainable. There are generally two perspectives regarding criteria for sustainable sanitation in literature: technology focused and best-practice oriented. Technology focused criteria are used to assess the impacts of the technologies themselves or make comparisons between them, using tools such as life cycle assessment (LCA) and environmental impact assessments. Criteria commonly cited among academics in international journals and conference papers fall into five main categories: health, environment, technical, economic, and socio-cultural factors. Several groups have developed comprehensive lists of indicators for technology assessment (Balkema et al., 2002; Dunmade, 2002; Bracken et al., 2005), a synthesized list of these criteria are shown in Table 2.

The second source of criteria of sanitation comes from the international development community, presenting lessons learned and best-practice recommendations for scaling-up sanitation projects. A list of such criteria can be derived from publications by the Water and Sanitation Program (WSP) of the World Bank (Wright, 1997; WSP, 2001; WSP, 2003; WSP, 2005; WSP, 2007).

When comparing the findings from the literature with the results from the interview study (Table 2), one can notice the higher focus on technical, health, and environmental criteria in the technology assessment literature. In contrast, the criteria found in the best practice literature more closely match the criteria present in the interview material, with its emphasis on socio-economic, cultural and procedural issues. 
Table 2: Comparison of sustainability criteria from interview study and literature review Interview Study

Socio-cultural
Capacity Development $\quad$ Perception of system (importance, compatibility)

Institutional Communication

Laws and Policy

Cultural Acceptability

Awareness-Raising

Behaviour Change

Economics

Affordable

Marketing

Financial Management

\section{Technical}

Adaptation to community System robustness (risk of failure, endure shock loading/abuse)

O\&M requirements

Ability to address awareness and information needs

Local competence for construction and O\&M

Local serviceability (accessible parts, technical expertise)

Ease of system monitoring

Compatibility with existing systems

Adaptability to user needs and environmental conditions

Capacity development (institutional and stakeholders)

Institutional network for political support and communication

Institutional incentives (fines, awards, enforcement)

Adapted to demand for sanitation (convenience, cleanliness)

Investment in hygiene promotion and demand creation

Focus on stopping open defecation (behaviour change)

Affordable for the poor (willingness to pay)

Apply commercial principles (enterprises, service contract)

Financial support from government

Subsidies for technical assistance, awareness promotion

Technical suitability to community

Operational efficiency for long-tem maintenance/management

Wider choice of technologies

Adapted to needs-based criteria (health, poverty, environment)

Risk of infection from pathogens

Risk of exposure to hazardous substances

Environment

Resource consumption (land, energy, materials, water)

Environmental releases to water, air, soil

Resource conservation (reuse, recycling)

Impact on biodiversity, land fertility, natural systems

Compliance with environmental standards

\begin{tabular}{cc} 
Process & $\begin{array}{c}\text { Participation } \\
\text { Participation } \\
\text { Planning } \\
\text { M\&E }\end{array}$ \\
\hline
\end{tabular}




\section{RESULTS: CASE STUDIES \\ WaterAid Mali}

WaterAid is an international NGO that works to provide support for local governments through the process of decentralization, good governance, and planning to enable them to meet the needs of the water/sanitation sector and the MDGs. They work at the municipal level to help local leaders to develop and implement sector plans for meeting water and sanitation needs. The approach uses participatory methods to build social capital by

reinforcing the capacities of the different actors, especially in regards decision-making capabilities and the management of local affairs. The development of the sector plan consists of five steps:

- Preparatory activities

- Data Collection

- Evaluation of data and creation of thematic maps

- Formulation of plan

- Validation of the plan with the local population and action planning

The preparatory activities include initial meetings to bring stakeholders into the process, explain expected outcomes, and the training of local field workers in participatory data collection techniques. This process allows WaterAid to identify the principle actors in the water/sanitation sector and their capacities (i.e. education levels of municipal council, organizational structure of water associations, and generally education level of the population). This is followed by the collection of data related to local water and sanitation conditions, both physical surveys of existing infrastructure and environmental conditions, and socio-economic perspectives of demand and need for sanitation. The data is collected by locally trained hygienists and masons who interact directly with the community. The collected data is initially processed by experts within WaterAid who use cartography and GPS systems to display the collected data. It is then validated by the community during two stakeholder workshops. These workshops lead into the planning process by generating discussions on priority actions, feasibility, acceptability and potential impacts of actions. During the planning process, WaterAid works with a planning committee, headed by the mayor and representative of the interests of the community, in order to provide training on organizational and planning techniques. The final document details a yearly plan of activities and budgets, including types of latrines to be provided to households, awareness-raising programs, and training of masons. Financing and M\&E of results are left to the responsibility of the municipality. This document is voted on by the municipal council and becomes the water/sanitation policy document for the municipality.

The relationship of the WaterAid planning process to the criteria identified in this study can be seen in Table 3. The strength of the approach lies in the heavy focus on participatory and capacity building efforts for data collection and planning techniques, especially at the local government level. The participatory process of data collection and validation with the community also addressed questions of cultural acceptability. Awareness-raising activities were included in the final planning document and project 
budget, even if few specifics activities or targets for behaviour change were written into the document.

The project is weak however, on economic and technical criteria. The plan does not provide specifics of technical designs or suggest appropriate systems. It does include organizing enterprises for emptying pit latrines, but the lack of other technology specifications means that O\&M requirements are also neglected. The data collection step included socio-economic information, but not specifics on willingness or capacity to pay for sanitation improvements. Combined with the low assessment of technical options, issues of affordability and financing appear to be given low priority. Although the planning document includes a budget for the activities, it does not specify how the projects will be financed. It is assumed that the municipality will find their own means of financing the projects.

Table 3: Interview criteria used in WaterAid and ONEA planning approaches

\begin{tabular}{|c|c|c|}
\hline Criteria from Interviews & WaterAid & ONEA \\
\hline \multicolumn{3}{|l|}{ Socio-cultural } \\
\hline Capacity Building & $\begin{array}{l}\text { Preparatory activities } \\
\text { Formulation of plan } \\
\text { Validation of plan }\end{array}$ & Pilot phase \\
\hline Institutional Collaboration & $\begin{array}{l}\text { Preparatory activities } \\
\text { Information collection } \\
\text { Formulation of plan }\end{array}$ & $\begin{array}{l}\text { Preliminary accords } \\
\text { Situational Analysis/Baseline Studies } \\
\text { Pilot phase }\end{array}$ \\
\hline Laws and Policy & Validation of plan (creating policy) & Official adoption of plan \\
\hline Cultural Acceptability & $\begin{array}{l}\text { Evaluation of data } \\
\text { Formulation of plan }\end{array}$ & Situational Analysis/Baseline Studies \\
\hline Awareness-Raising & $\begin{array}{l}\text { To be address during implementation } \\
\text { (promotional activities) }\end{array}$ & Pilot phase \\
\hline \multicolumn{3}{|l|}{ Economics } \\
\hline Affordable & -------------------------- & Situational Analysis/Baseline Studies \\
\hline Marketing & $\begin{array}{l}\text { To be address during implementation } \\
\text { (formation of enterprises) }\end{array}$ & Pilot phase \\
\hline Financial Management & ------------------------- & Situational Analysis/Baseline Studies \\
\hline \multicolumn{3}{|l|}{ Technical } \\
\hline $\begin{array}{l}\text { Adaptation to local } \\
\text { community } \\
\text { O\&M requirements }\end{array}$ & $\begin{array}{l}\text { Information collection } \\
\text { Evaluation of data }\end{array}$ & Situational Analysis/Baseline Studies \\
\hline \multicolumn{3}{|l|}{ Process } \\
\hline Participation & $\begin{array}{l}\text { Preparatory activities } \\
\text { Information collection } \\
\text { Evaluation of data } \\
\text { Formulation of plan } \\
\text { Validation of plan }\end{array}$ & $\begin{array}{l}\text { Preliminary accords } \\
\text { Situational Analysis/Baseline Studies } \\
\text { Stakeholder workshops } \\
\text { Detailing strategic plan }\end{array}$ \\
\hline Planning & $\begin{array}{l}\text { Preparatory activities } \\
\text { Formulation of plan }\end{array}$ & Detailing strategic plan \\
\hline Monitoring and Evaluation & Following implementation of plan & Monitoring and evaluation \\
\hline
\end{tabular}

\section{National Office for Water and Sanitation, Burkina Faso}

The growing problems of sanitation in the city of Ouagadougou lead the government of Burkina Faso to draft the Strategic Plan for Sanitation (PSAO). Implemented by the National Office for Water and Sanitation (ONEA), the PSAO rests on a strategic approach to devise sanitation solutions that are demand responsive, flexible, involve the 
active participation of stakeholders, and the innovative use of a sanitation surtax on the drinking water for financing the program (ONEA, 1993; WSP, 2002).

The planning process used for the PSAO and subsequently recommended by ONEA for other urban areas in Burkina Faso is composed of a series of steps and baseline studies (ONEA, 2007). The first step lays out the (i) preliminary accords between the municipality and ONEA. During this step a project team, containing both technical and sociological experts, is established for guiding the process. The cornerstone of the strategic approach is the (ii) situational analysis that will allow the plan to be adapted to the local constraints and opportunities. The analysis starts with an initial workshop to build cohesion with principal stakeholders and identify existing sources of information. This is followed by a series of baseline studies to obtain specific information on existing types of sanitation, user willingness to pay, living conditions, geography/soils, technology strategies, studies of desires/priorities, environmental feasibility, institutional and financial situation. The execution strategy is then defined during a (iii) pilot phase where possible sanitation options identified by ONEA technicians are demonstrated in specific areas of the city. In addition to assessing technical feasibility, the pilot project is a method for clarifying the roles and responsibilities of different institutions implicated in the process, and judging the need for capacity reinforcement. This stage also includes social marketing of sanitation, awareness-raising, and an elaboration of tools that will be used for project implementation. The process also included (iv) stakeholder workshops to confirm the results of the situational analysis and demonstration project with the community. Based on the pilot project and stakeholder input, possible sanitation options are identified by ONEA technicians and details are laid out in the (v) strategic plan. The strategic plan also includes a plan for monitoring and evaluation to assure the pertinence, efficiency and sustainability of the actions taken. The (vi) final plan is voted on by the municipal counsel and becomes the political policy for sanitation in the city.

The relationship of the ONEA planning process to the criteria identified in this study can be seen in Table 3. The strengths of the ONEA approach lie in financial management and the focus on on-site sanitation as an affordable option for the population. The success of this approach is linked to the establishment of institutional arrangements between the government and ONEA that allow for financial and managerial independence over the program direction. In addition, key features of the approach include offering households a variety of options and allowing them to choose according to their preference; and the use of social development tools to promote education and demand appropriate solutions.

Although the planning documents for the PSAO contain more technical designs and cost estimates than the WaterAid case, there is still little emphasis on O\&M so that desludging of latrines and treatment of sludge remain a problem. There is also evidence that benefits and subsidies go mostly to the middle class who have more access to information (WSP, 2002), which indicates weaknesses in communication, participatory frameworks and inequity in capacity development efforts. According to representatives of ONEA there are still economic challenges to overcome; the sanitation tax is limited and costs of technologies and promotional activities are high, making it difficult to reach all sectors of the city. Since the program is run through a national level agency there has been limited 
organization/institutional capacity building and there continues to be discrepancies with the responsibilities that are given to the city of Ouagadougou through the process of decentralization and the flow of financial resources (WSP, 2002).

\section{CONCLUSIONS}

This study highlights some key differences in perspectives between local practitioners in the field and criteria-based sanitation assessment tools. The criteria identified in the interview study are based on a definition of sustainable sanitation as a continuously functioning system that can be managed without outside support. From this perspective, actors in the West African sanitation sector stress the need to reinforce behaviour change, develop local capacities and establish long-term financing mechanisms. For them, achieving sustainable sanitation systems is a process rather than choice of technology. The importance of process criteria in sustainability can be seen in how closely they link to methods for communication, capacity building, empowerment, understanding of cultural issues, and discussions leading to informed user choice. It is also interesting to note that criteria related to health and environmental factors were rarely mentioned related to sustainability in the interviews. Perhaps it is assumed that a functioning, sustainable system will provide these benefits, and that by fulfilling the other criteria, specifically technical ones, health and environmental improvements will be achieved.

Results of the literature study revealed two dominant perspectives: the academic, technology-based assessments which include more technical, health, and environmental criteria; and the development agencies which offer more policy oriented best-practice recommendations. The answers received from the interview study tend to agree with best-practice criteria, perhaps because at a local level these actors are more closely linked to the implementation process in the field. However, both the academic and pragmatic perspectives are valid and a truly sustainable system will be one that can recognize both sides by addressing the technical requirements and social change processes together.

Compared to the literature review, the case studies show a better integration of technical and process criteria. Both WaterAid and ONEA mix participatory planning techniques with technical baseline studies. However, neither has completely succeeded in achieving a balanced portfolio. WaterAid focuses on capacity development but makes fewer provisions for technical and economic issues. In contrast, technical and financing measures are more clearly defined by ONEA, although they still struggle with O\&M issues and extending the program to reach all stakeholders.

Achieving sanitation coverage targets and insuring the longevity and functionality of the systems requires the cooperation and involvement of a wide variety of stakeholders. There is an enormous amount of experience, expertise, and differing perspectives among the various actors in the field of sanitation. Future research should expand this type of questioning to include knowledge from a broader range of local and global stakeholders, and compare them to additional projects and planning frameworks. The solution to the sanitation challenge will involve understanding and merging these perspectives into a comprehensive approach. 


\section{ACKNOWLEDGEMENTS}

The authors would like to thank all the participants in the interview study for their time and insights, as well as the staff at CREPA headquarters for logistical support and hospitality. Financial support for Ms. McConville was provided by the US National Science Foundation Graduate Research Fellowship Program.

\section{REFERENCES}

Balkema, A.J. et al. (2002). Indicators for the Sustainability of Wastewater Treatment Systems. Urban Water, 4, 153-161.

Bracken, P., Kvarnström, E., Ysunza, A., Kärrman, E., Finnson, A., and Saywell, D. (2005). Making sustainable choices - development and use of sustainability oriented criteria in sanitary decision-making. Proceedings of the $3^{\text {rd }}$ International Ecological Sanitation Conference, 486-494.

Dunmade, Israel. (2002). Indicators of sustainability: assessing the suitability of a foreign technology for a developing country. Technology in Society, 24, 461-471.

Eawag: Swiss Federal Institute of Aquatic Science and Technology. (2005). HouseholdCentred Environmental Sanitation: Implementing the Bellagio Principles in Urban Environmental Sanitation. Eawag, Duebendorf, Switzerland.

Hellström, Daniel, Jeppsson, Ulf, and Kärrman, Erik. (2000). A framework for systems analysis of sustainable urban water management. Environmental Impact Assessment Review, 20, 311-321.

International Water Association (IWA). (2006). Sanitation 21: Simple Approaches to Complex Sanitation, a Draft Framework for Analysis. International Water Association, London, UK.

Lundin, Margareta, and Morrison, Gregory M. (2002) A life cycle assessment based procedure for development of environmental sustainability indicators for urban water systems. Urban Water, 4, 145-152.

McConville, J.R. and Mihelcic, J.R. (2007). Adapting Life Cycle Thinking Tools to Evaluate Project Sustainability in International Water and Sanitation Development Work. Environmental Engineering Science, 24 (7), 963-974.

Office Nationale de l'Eau et de l'Assainissement (ONEA). (1993). Plan Stratégique d'Assainissement des eaux usées de la ville de Ouagadougou (PSAO). National Office of Water and Sanitation, Burkina Faso.

Office National de l'Eau et de l'Assainissement (ONEA). (2007). Note d'orientation pour l'élaboration de plans stratégiques d'assainissement des eaux usées et excréta dans 
les centres urbains et semi urbains du Burkina Faso. National Office of Water and Sanitation, Burkina Faso.

Van der Vleuten-Balkema, A. (2003). Sustainable Wastewater Treatment - Developing a Methodology and Selecting Promising Systems. Doctoral thesis from Technische Univesiteit Eindhoven: Eindhoven University Press, The Netherlands.

Wright, A. (1997). Toward a Strategic Sanitation Approach: Improving the Sustainability of Urban sanitation in Developing Countries. Washington, DC, USA: UNDP-World Bank Water and Sanitation Program. http://www.environmentintegration.org/Download/E33d_Water/global_ssa.pdf (accessed 30 March 2008).

Water and Sanitation Program (WSP). (2001). Achieving Sustained Sanitation for the Poor: Policy and Strategy Assessments from Participatory Assessments in Cambodia, Indonesia, Vietnam, Report \#27002. WSP- East Asia and Pacific, Jakarta, Indonesia.

Water and Sanitation Program-Africa Region. (2002). Field Note: The Ouagadougou Strategic Sanitation Plan: An Holistic Approach to a City's Problems. WSP Africa Region, Nairobi, Kenya.

Water and Sanitation Program (WSP). (2003). Field Note: Urban Sewerage and Sanitation: Lessons learned from case studies in the Philippines. WSP- East Asia and Pacific, Jakarta, Indonesia.

Water and Sanitation Program (WSP). (2005). Scaling-Up Rural Sanitation in South Asia: Lessons Learned from Bangladesh, India, and Pakistan, Report \#34873. WSPSouth Asia, New Delhi, India.

Water and Sanitation Program (WSP). (2007). From Burden to Communal Responsibility A Sanitation Success Story from Southern Region in Ethiopia. WSPHygiene and Sanitation Series, Nairobi, Kenya. 